\author{
Е.А. Королюк \\ B.М. Доронькин ${ }^{*}$
}

«Имена собственные отдельных сибирских растений»: выставка Ботанического музея Сибири

doi:10.31518/2618-9100-2021-2-9

УДК 069.5:58.007 + 58.006 (571.1/.5)

Выходные данные для цитирования:

Королюк Е.А., Доронькин В.M. «Имена собственные отдельных сибирских растений»: выставка Ботанического музея Сибири // Исторический курьер. 2021. № 2 (16). С. 112-117. URL: http://istkurier.ru/data/2021/ISTKURIER-2021-209.pdf

\author{
E.A. Korolyuk \\ V.M. Doronkin*
}

\section{“The Proper Names of Some \\ Siberian Plants": The Exhibit of the Botanical Museum of Siberia}

doi:10.31518/2618-9100-2021-2-9

How to cite:

Korolyuk E.A., Doronkin V.M. "The Proper Names of Some Siberian Plants": The Exhibit of the Botanical Museum of Siberia // Historical Courier, 2021, No. 2 (16), pp. 112-117. [Available online:] http://istkurier.ru/data/2021/ISTKURIER-2021-209.pdf

Abstract. The article is devoted to the temporary exhibit "Proper names of some Siberian plants" marking the $75^{\text {th }}$ anniversary of the Central Siberian Botanical Garden of the Siberian Branch of the Russian Academy of Sciences (CSBG SB RAS, Novosibirsk). The names of 19 botanists from CSBG were memorized in 43 plants represented by angiosperms (1 genus, 37 species and 2 subspecies), lichens and algae (1 genus and 2 species each). The article contains information about the taxa and the personalities whose names were offered for the plants' proper names. Their biography and contribution to botanical science are described in brief, as well as the historical facts that motivated their colleagues to give the proper names to the new taxa (species, genera and hybrids). It is worth mentioning that such naming was invigorated by the increased rates of investigations of Siberian vegetation and its floristic composition, and by subsequent generalization of these data into the large floristic works printed in the $20^{\text {th }}$ century with personal contribution of the botanists of the Central Siberian Botanical Garden, SB RAS.

Keywords: Siberia; Botanical Museum of Siberia; CSBG SB RAS; proper names of angiosperms; lichens and algae taxa; the history of botanical investigations.

The article has been received by the editor on 25.02.2021.

Full text of the article in Russian and references in English are available below.

Аннотация. В Ботаническом музее Сибири (ЦСБС СО РАН, г. Новосибирск) в связи с 75-летним юбилеем сада была организована временная экспозиция «Имена собственные некоторых сибирских растений (патронированные таксоны)». Патронация была произведена в честь 19 ботаников Центрального сибирского ботанического сада СО РАН - это 1 род, 37 видов и 2 подвида цветковых растений, по 1 роду и 2 видам среди лишайников и водорослей. В статье обобщаются данные о собственно таксонах, о личностях, в честь которых были предложены имена собственные. Кратко описан вклад ботаников в науку, приведены биографические данные, исторические факты, раскрывающие мотивацию присвоения новым таксонам (видам, родам, гибридам) имен сотрудников ботанического сада. Отмечается, что практика наименования связана с активизацией работ по исследованию растительности

\footnotetext{
* Королюк Елена Анатольевна, кандидат биологических наук, Центральный сибирский ботанический сад Сибирского отделения Российской академии наук, Новосибирск, Россия, e-mail: 1_koroljuk@ngs.ru

Доронькин Владимир Михайлович, кандидат биологических наук, Центральный сибирский ботанический сад Сибирского отделения Российской академии наук, Новосибирск, Россия, e-mail: norbo@ngs.ru

Korolyuk Elena Anatol'evna, Candidate of Biological Sciences, Central Siberian Botanical Garden of the Siberian Branch of the Russian Academy of Sciences, Novosibirsk, Russia, e-mail: 1_koroljuk@ngs.ru

Doronkin Vladimir Mikhailovich, Candidate of Biological Sciences, Central Siberian Botanical Garden of the Siberian Branch of the Russian Academy of Sciences, Novosibirsk, Russia, e-mail: norbo@ngs.ru
} 
Сибири, ее флористического состава и обобщению этих материалов в крупных флористических трудах, которые вышли в XX столетии при непосредственном участии ботаников Центрального сибирского ботанического сада СО РАН.

Ключевые слова: Сибирь; Ботанический музей Сибири; ЦСБС СО РАН; патронированные таксоны цветковых растений, лишайников, водорослей; история ботанических исследований.

Ботанический музей Сибири Центрального сибирского ботанического сада СО РАН (далее ЦСБС СО РАН) создан в 1993 г. Наряду с многочисленными экспозициями живых растений открытого и закрытого грунта «Музей» входит в комплекс объектов сада, предназначенных для популяризации ботаники как науки. Все экспонируемые в музее материалы

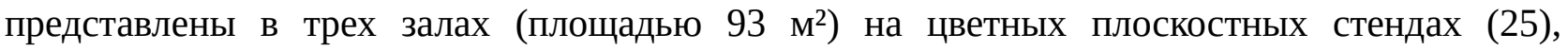
в 23 витринах, а также в архивных фондах (около 450 единиц хранения). Во всех залах находятся постоянные экспозиции, которые служат основой для проведения экскурсий. Кроме того, ежегодно, на протяжении последних 13 лет в рамках проведения «Дней Науки» кураторы музея готовят временную (действующую в течение года) новую экспозицию, сопровождая ее тематической лекцией-экскурсией. Тематические выставки имеют узкоспециальную тематическую направленность, к их разработке кураторы привлекают специалистов разного профиля, работающих в ботаническом саду. В дальнейшем эти временные экспозиции размещаются на разных площадках вне института.

Центральному сибирскому ботаническому саду СО РАН в 2021 г. исполняется 75 лет. Юбилейные даты дают возможность обратиться к истории и более глубоко оценить вклад ученых-исследователей ЦСБС в ботаническую науку. В текущем году родилась идея познакомить широкую публику с растениями, которые были названы в честь сотрудников института. Реализацией этой идеи стала тематическая временная выставка «Имена собственные некоторых сибирских растений» на площадке «Ботанического музея Сибири».

Источниками для подготовки экспозиции и статьи послужили научные издания по теме, материалы из архивов «Ботанического музея Сибири», ЦСБС СО РАН. В частности, использованы материалы биоресурсной научной коллекции ЦСБС СО РАН «Гербарий высших сосудистых растений, лишайников и грибов (NS, NSK)», УНУ № USU 440537. Важное значение имели фотоматериалы и разработки сотрудников ЦСБС СО РАН (И.В. Хан, С.В. Овчинниковой - лаборатория систематики сосудистых растений, Н.В. Седельникововой, Т.В. Макрый, Ю.В. Науменко - лаборатория низших растений, А.Ю. Королюк - лаборатория геоботаники).

Во многих областях науки принято давать имена объектам исследований в честь учителей или научных лидеров, создавая таким образом «нерукотворный памятник» деятелям науки, внесшим наиболее заметный вклад в ее развитие. Так, часто именами собственными называют новые звезды и галактики, острова и вулканы, морские течения и горные хребты, виды растений и животных, химические реакции, коллекции, исследовательские центры-список огромен. Растения, названные в честь исследователей или первооткрывателей новых растений называются патронированными. Во флоре Сибири множество растений носят имена первооткрывателей. В этих названиях сохранена память об известных натуралистах и ботаниках прошлого - Иоганне Гмелине, Степане Крашенинникове, Николае Турчанинове, Петре Палласе, Георге Стеллере, Порфирии Крылове, Лидии Сергиевской.

В XX-XXI столетиях ботанические исследования все более расширяются, и новые таксоны получают новые имена, в которых запечатлено уважение к труду исследователей природы. За 75-летний период в ботаническом саду работала большая команда исследователей флоры огромного пространства - Сибири, и по крайней мере 19 фамилий сибирских ботаников, работавших в Центральном сибирском ботаническом саду с момента его организации, остались для потомков в названиях 43-х таксонов разного ранга - от названия подродовой секции, рода, вида, до подвида и иных категорий сосудистых растений, лишайников, водорослей. Свои имена увековечили в названиях флоры наши коллеги-ботаники. 
Это Г.Р. Азовцев, Т.А. Вагина, Н.С. Водопьянова, Н.В. Власова, А.А. Красников, И.М. Красноборов, А.В. Куминова, Н.Н. Лащинский (ст.) и Н.Н. Лащинский (мл.), М.Н. Ломоносова, Л.И. Малышев, З.Д. Малышева, Г.А. Пешкова, Т.Г. Попова, Н.В. Седельникова, А.П. Скабичевский, К.А. Соболевская, Д.Н. Шауло, В.М. Ханминчун. В их честь названы роды, виды и иные таксономические категории из семейств: Злаки, Осоковые, Гвоздичные, Розовые, Бобовые, Лютиковые, Бурачниковые, Фиалковые, Горечавковые, Крестоцветные, Лилейные, Гераниевые, Астровые.

Прежде всего, это было связано с тем, что в XX столетии активно осуществлялись работы по исследованию растительности Сибири, ее флористического состава и обобщению этих материалов, потребовало от ботаников огромного труда и немалого мужества. Были обследованы неизведанные, труднодоступные территории Сибири, собраны обширные гербарные коллекции, хранящиеся в настоящее время в одном из крупнейших гербариев России в ЦСБС. Коллекции, охватывающие в основном территории Западной Сибири и Республики Тыва, хранятся в Гербарии имени профессора Ивана Моисеевича Красноборова (часть этой коллекции носит специальную аббревиатуру «NS») ${ }^{1}$. Вторая часть Гербария носит имя чл.-корр. Украинской АН, профессора Михаила Григорьевича Попова, здесь хранятся обширные гербарные коллекции из Восточной Сибири «NSK». Основная часть этой коллекции в 1978 г. была перевезена из Иркутска. В этих гербарных фондах хранится большинство типовых образцов растений (образцов, с которых проводилось описание новых таксонов), носящих имена ботаников сада. В настоящее время проводятся работы по оцифровке гербарных коллекций, в т.ч. и типовых образцов, которые будут доступны широкой научной общественности.

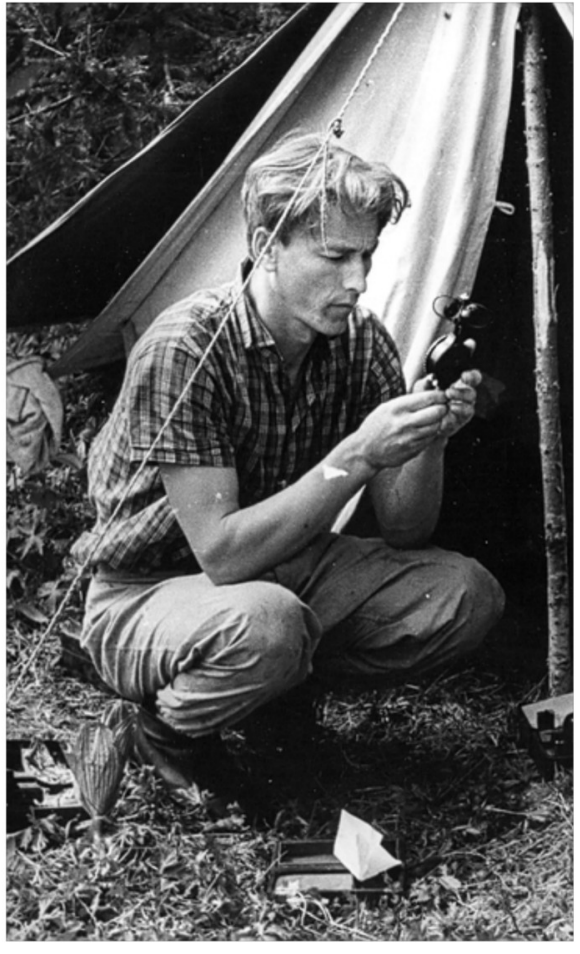

Рис. 1. Иван Моисеевич Красноборов в экспедиции, 1960-е гг.

Фото из архивов лаборатории Гербарий.

В честь профессора, доктора биологических наук

Галины Александровны Пешковой (1930-2018)² был выделен род Пешковия (семейство Гвоздичные) коллегой из Ботанического института им. В.Л. Комарова АН СССР (Ленинград- СПб.) профессором Николаем Николаевичем Цвелёвым (1925-2015). Из лишайниковых, по результатам молекулярно-генетических исследований и некоторых особенностей строения органов размножения, был выделен род Седельниковия (2015), названный в честь крупнейшего сибирского лихенолога, профессора, доктора биологических наук Нелли Васильевны Седельниковой. Виды этого рода встречаются в континентальной Азии ${ }^{3}$. В честь профессора, д-ра биол. наук Александра Павловича Скабичевского (19041990) среди диатомовых водорослей был описан новый род Скабичевския (2015), виды которого обитают в пресных водах Голарктики. В честь Александра Павловича описана другая водоросль цимбелла Скабичевского (1959). В честь старейшей сотрудницы сада, одной из основателей лаборатории низших растений, доктора биологических наук Татьяны Григорьевны Поповой (1898-1992) ${ }^{4}$ Г.Д. Левадной описана водоросль гомфонема Поповой (1990)

\footnotetext{
${ }^{1}$ Шауло Д.Н., Доронькин В.М., Шмаков А.И. Иван Моисеевич Красноборов (21.04.1931-27.10.2011) // Turczaninowia. 2013. Т. 16, № 2. С. 138-155.

${ }^{2}$ Овчинникова С.В. Галина Александровна Пешкова (к 80-летию со дня рождения) // Растительный мир Азиатской России. 2011. Т. 1. С. 99-106.

${ }^{3}$ Макрый T.B. Sedelnikovaea baicalensis (Lecanoraceae) - новый для Европы род и вид лишайника // Новости систематики низших растений. 2018. Т. 52, № 2. С. 407-416.

${ }^{4}$ Науменко Ю.В., Ермолаев В.И. Татьяна Григорьевна Попова (к 110-летию со дня рождения) // Ботанический журнал. 2009. Т. 94, № 3. С. 470-473.
} 
и Н.В. Седельниковой-лишайник аспицилия Поповой (1984). Она же описала еще один вид лишайника плакодиум Куминовой (1982), носящий имя в честь крупнейшего сибирского геоботаника, профессора, доктора биологических наук, бессменного руководителя крупнейшей лаборатории геоботаники в бывшем СССР - Александры Владимировны Куминовой (1911-1997)

Среди цветковых растений наибольшее количество видов было описано в честь профессора, Д-ра биол. наук Леонида Ивановича Малышева (1931-2014). Исследователь высокогорной флоры Восточного Саяна, горных массивов Восточной Сибири, он был инициатором и одним из организаторов проекта по изучению флоры Сибири, итогом которого стала многотомная «Флора Сибири», изданная в 1987-2003 гг. ${ }^{6}$ В его честь названо 10 новых для науки видов из Сибири. Виды были описаны как коллегами из Ленинграда (Санкт-Петербурга), так и его учениками, работавшими с ним в период выполнения проекта и продолжающими делать описание новых видов в настоящее время в ЦСБС. Некоторые из описанных видов являются эндемиками Сибири. В честь Малышева описаны: осока Малышева (1968), ковылечек Малышева (1974), лапчатка Малышева (1979), горечавочка Малышева (1985), болотник Малышева (1987), лук Малышева (1987), шпорник Малышева (1990), овсяница Малышева (1990), кострец Малышева (2016), герань Малышева (2017). В ботанических экспедициях принимала участие Зинаида Дмитриевна Беспалова, впоследствии ставшая его женой. В честь нее Леонидом Ивановичем была описана стевения Зинаиды .

В коллективе единомышленников с Леонидом Ивановичем трудились и участвовали в экспедиционных работах коллеги, в честь которых также были названы новые для науки виды растений. В честь профессора, доктора биологических наук Галины Александровны Пешковой (1930-2018) патронированы следующие виды: эндемик побережий Байкала остролодочник Пешковой (1957), пырейник Пешковой (2008) и полевица Пешковой (2010). Нинель Семёновна Водопьянова (1932-1983), кандидат биологических наук, исследователь Центральной Сибири, участник проекта «Флора Сибири» удостоена патронацией четырех видов: это эндемик плато Путорана - щучка Водопьяновой (1987), а также гвоздика Нинели (1979), лук Водопьяновой (1985) и сокольница Водопьяновой (1997).

С острова Ушканий (оз. Байкал) кандидатом биологических наук Натальей Васильевной Власовой был намечен к описанию в гербарии Ботанического института (Ленинград) новый вид эндемичного злака тонконога, но не был описан. Николай Николаевич Цвелёв в 2011 г. описал его и назвал в ее честь - тонконог Власовой.

Исследователь высокогорной флоры Западного Саяна, флоры Тывы, флоры Западной Сибири, один из организаторов и исполнителей проекта «Флора Сибири», крупный флорист - Иван Моисеевич Красноборов (1931-2011). В его честь патронировано восемь новых таксонов: эндемик Тувы и Монголии - канкриния Красноборова (1983), мятлик Красноборова (1994), бореч Красноборова (1994), одуванчик Красноборова (1998),

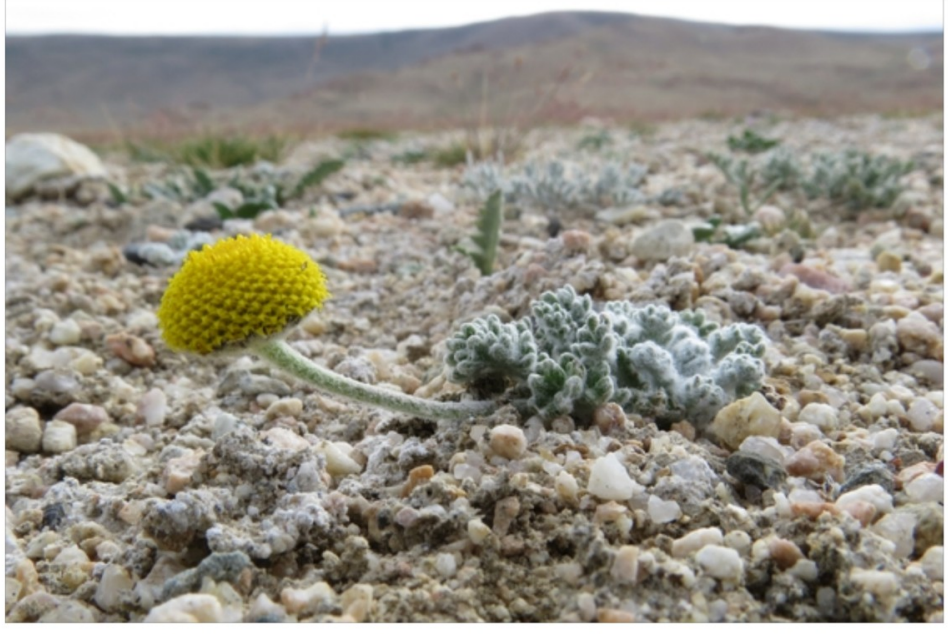

Puc. 2. Канкриния Красноборова. Монголия, 2019 г. Эндемичный вид, названный в честь профессора, д-ра биол. наук И.В. Красноборова. Фото А.Ю. Королюка.

\footnotetext{
${ }^{5}$ Александра Владимировна Куминова - сибирский геоботаник и флорист. Новосибирск, 2006.

${ }^{6}$ Флора Сибири: в 14 т. Новосибирск, 1987-2003.

${ }^{7}$ Доронькин В.М. Леонид Иванович Малышев (к 80-летию со дня рождения) // Ботанический журнал. 2011. Т. 96, № 4. С. 533-546.
} 
горькуша Красноборова (2004), незабудка Красноборова (2004), солодка Красноборова (2011), вероника Красноборова (2019). В экспедициях по исследованию флоры Тувы, Алтая и других регионов Сибири принимали участие его многочисленные ученики и коллеги, в честь которых также названы ранее неизвестные виды растений.

Изучая лекарственные растения на Алтае, Григорий Романович Азовцев (1925-1991) собрал в экспедиции неизвестный вид кровохлебки, который и был назван в его честь как кровохлебка Азовцева (1986), вид - эндемик Горного Алтая. Валерий Михайлович Ханминчун (1945-1996), флорист, кандидат биологических наук, плодотворно работал в Туве, на Алтае. Коллеги из Южно-Сибирского ботанического сада Алтайского государственного университета (Барнаул) увековечили его имя в названии двух эндемичных видов из Горного Алтая: это борец Ханминчуна (1997) и лапчатка Ханминчуна (1997). Дмитрий Николаевич Шауло, Мария Николаевна Ломоносова, Александр Анатольевич Красников оставили свои имена в следующей патронации: фиалка Шауло (2007), тысячелистник Шауло (2016), скерда Ломоносовой (2007), одуванчик Красникова (2011).

Вторым директором ЦСБС АН СССР с 1950 по 1971 гг. была Кира Аркадьевна Соболевская (1911-1999). Она одна из первых в советский период исследовала флору и лекарственные растительные ресурсы Тувы. Коллеги из Томского университета, в котором она училась, назвали в ее честь астрагал Соболевской (1963), мятлик Соболевской (1963), остролодочник Соболевской (2013). С.К. Черепнин (1921-1995), коллега из Ботанического института (Ленинград) в честь Киры Аркадьевны переименовал один из таксонов в смолевку Соболевской (1981).

Вагина Тамара Алексеевна (1916-2002) - старейший сотрудник сада, кандидат биологических наук, геоботаник. Ветеран Великой Отечественной войны, во время войны была медсестрой, снайпером. В мирное время исследовала кормовые угодья в Барабе (Новосибирская область, Западная Сибирь). По ее сборам, при работе над обработкой семейства «злаки» для издания «Флора Сибири», С.В. Бубновой был описан новый эндемичный вид, названный в ее честь - бескильница Вагиной (1990).

Лащинский Николай Николаевич (1926-2015) - доктор биологических наук, геоботаник, также один из старейших сотрудников сада, участник Великой Отечественной войны. По его сборам из Западной Сибири, при подготовке одного из томов «Флоры Сибири» Н.Н. Золотухиным был описан новый эндемичный вид, который получил название гусиный лук Лащинского (1987). В.В. Зуев, обрабатывая сборы фиалок из коллекции гербария ЦСБС для 10-го тома «Флоры Сибири», обнародовал новый для науки эндемичный подвид - фиалку Лащинского (1996), названный в честь Николая Николаевича Лащинского (мл.), доктора биологических наук, геоботаника, специалиста в области популяционных исследований.

Тематическая временная выставка «Имена собственные некоторых сибирских растений» на площадке «Ботанического музея Сибири», подготовленная к юбилею Центрального сибирского ботанического сада СО РАН в 2021 г., будет интересна как профессиональным ботаникам, так и широкой публике, а ее материалы послужат контентом последующих мемориальных выставок. В экспозиции представлены фотографии растений или их отсканированные типовые образцы. Приведена атрибутация: латинское и русское название, его таксономическая принадлежность, автор, дата описания таксона, издание, рисунки, сопровождающие публикации материалов об образцах. Представлены фотографии ботаников-первооткрывателей, их биографические данные, факты профессиональной деятельности, примечательные обстоятельства, при которых возникли наименования вновь открытых образцов флоры.

Таким образом, в ходе подготовки данной выставки кураторы Ботанического музея Сибири» обобщили разрозненные данные о патронированных растениях Сибири с целью отдать дань памяти и уважения исследователям-ботаникам, привлечь внимание широкой общественности к научно-исследовательской деятельности ЦСБС СО РАН. Изучение сибирской флоры продолжается, и следует ожидать описаний новых таксонов, названных в честь ботаников Центрального сибирского ботанического сада СО РАН. 


\section{Лumepamypa}

Александра Владимировна Куминова - сибирский геоботаник и флорист / отв. ред. В.П. Седельников. Новосибирск: Академическое издательство «Гео», 2006. 115 с.

Доронькин B.M. Леонид Иванович Малышев (к 80-летию со дня рождения) // Ботанический журнал. 2011. Т. 96, № 4. С. 533-546.

Макрый T.B. Sedelnikovaea baicalensis (Lecanoraceae) - новый для Европы род и вид лишайника // Новости систематики низших растений. 2018. Т. 52, № 2. С. 407-416.

Науменко Ю.В., Ермолаев В.И. Татьяна Григорьевна Попова (к 110-летию со дня рождения) // Ботанический журнал. 2009. Т. 94, № 3. С. 470-473.

Овчинникова С.В. Галина Александровна Пешкова (к 80-летию со дня рождения) // Растительный мир Азиатской России. 2011. Т. 1. С. 99-106.

Флора Сибири: в 14 т. Новосибирск: Наука, 1987-2003. 3921 с.

Шауло Д.Н., Доронькин В.М., Шмаков А.И. Иван Моисеевич Красноборов (21.04.193127.10.2011) // Turczaninowia. 2013. T. 16, № 2. С. 138-155.

\section{References}

Doronkin, V.M. (2011). Leonid Ivanovich Malyshev (in the $80^{\text {th }}$ Birthday) [Leonid Ivanovich Malyshev (in the 80 ${ }^{\text {th }}$ Birthday)]. In Botanicheskiy Zhurnal. Vol. 96, No. 4, pp. 533-546.

(1987-2003) Flora Sibiri [Flora of Siberia]: in 14 vols. Novosibirsk. Nauka. 3921 p.

Makryy, T.V. (2018). Sedelnikovaea baicalensis (Lecanoraceae) - novyy dlya Evropy rod i vid lischaynika [Sedelnikovaea baicalensis (Lecanoraceae) - a new genus and species of lichen for Europe]. In Novosti sistematiki nizshikh rasteniy. Vol. 52, No. 2, pp. 407-416.

Naumenko, Yu.V., Ermolaev, V.I. (2009). Tatyana Grigorievna Popova (on the 110-Years Anniversary) [Tatyana Grigorievna Popova (k 110-letiyu so dnya rozdeniya)]. In Botanicheskiy Zhurnal. Vol. 94, No. 3, pp. 470-473.

Ovchinnikova, S.V. (2011). Galina Aleksandrovna Peschkova (on the $80^{\text {th }}$ birthday) [Galina Aleksandrovna Peschkova (on the $80^{\text {th }}$ birthday)]. In Rastitelnyy mir Aziatskoy Rossii. Vol. 1, pp. 99-106.

Sedelnikov, V.P. (Ed.) (2006). Aleksandra Vladimirovna Kuminova - sibirskiy geobotanik $i$ florist [Aleksandra Vladimirovna Kuminova - siberian geobotanist and florist]. Novosibirsk, Akademicheskoe izdatelstvo "Geo". 115 p.

Shaulo, D.N., Doronkin, V.M., Shmakov, A.I. (2013). Ivan Moiseyevich Krasnoborov (21.04.1931-27.10.2011) [Ivan Moiseyevich Krasnoborov (21.04.1931-27.10.2011)]. In Turczaninowia. Vol. 16, No. 2, pp. 138-155.

Статья поступила в редакцию 25.02.2021 г. 